\title{
Selected Heavy Metals in Penaeus vannamei (White Prawn) in Aquaculture Pond near Likas Lagoon, Sabah, Malaysia
}

\author{
Wei Peng Lee, Carolyn Payus, Siti Aishah Mohd Ali, and Leong Wan Vun
}

\begin{abstract}
The issue of heavy metal toxicity has received considerable attention in aquaculture field. Most studies of heavy metal in aquaculture have only focused on fish species and molluses but not prawn. Thus, the key research objective of this study is to identify and study selected heavy metals in Penaeus vannamei in the study area. In this study, the mature prawns (5 months old) were collected and $1 \mathrm{~g}$ of sample is digested using $\mathrm{H}_{2} \mathrm{SO}_{4}$ and $\mathrm{HNO}_{3}$ for 2 hours and filtered. The heavy metal concentration in prawn samples is determined using ICP-OES. The major heavy metals in the prawn head and shell are dominated by $\mathrm{Fe}>\mathrm{Cu}>\mathrm{Zn}>\mathrm{Cr}>\mathrm{Mn}>\mathrm{Ni}$ while in prawn flesh is $\mathrm{Fe}>\mathrm{Zn}>\mathrm{Cu}>\mathrm{Cr}>\mathrm{As}>\mathrm{Ni}>\mathrm{Mn}$. In this study, the highest heavy metals toxicity are prawn head> prawn shell> prawn flesh. In this study, it was found that most of the heavy metals are accumulated in the head of prawn whereas the least is in the shell of prawn.
\end{abstract}

Index Terms-Aquaculture, bioaccumulation, heavy metal pollution, Penaeus vannamei.

\section{INTRODUCTION}

Aquaculture is the currently fastest growing food producing sector in the world. This is due to high demands from the consumers. Aquaculture industry plays an important role for food security, food nutrition and income generation. However, the food security and nutrition aspects are often neglected. Researchers foresee that aquaculture industry will face four inevitable challenges which are increase cultivable areas without decreasing biodiversity or increase water demand, improving food quality, producing ecosystem services and adapting to climate changes [1]. Hence, it is necessary to design aquaculture systems which use fewer chemical products, more renewable resources and make the best use of ecosystem services without impairing their regeneration.

Estuaries and coastal area exhibit a wide array of human impacts that can compromise their ecological integrity, because of rapid population growth and uncontrolled

Manuscript received November 4, 2016; revised February 15, 2017. This work was supported by project grant of NRGS0005 under Ministry of Higher Education, Malaysia.

W. P. Lee is with Environmental Science at the Faculty of Science and Natural Resources of Universiti Malaysia Sabah, Malaysia (e-mail: sky_blue9115@hotmail.my, skyblue9115@gmail.com).

C. M. Payus is with Environmental Science Programme, Faculty of Science and Natural Resources in Universiti Malaysia Sabah, Malaysia (e-mail: melpayus@ums.edu.my).

Siti Aishah Mohd Ali is with Universiti Malaysia Sabah, Malaysia.

L. W. Vun is with Faculty of Science and Natural Resources in Universiti Malaysia Sabah, Malaysia (e-mail: bvun@ums.edu.my, bvunlw@gmail.com). development in many coastal regions worldwide. Hence, aquaculture which uses water from the river, estuary and coastal area is prone to external pollution and the produce (fish, prawns) can be a health risk if consumed. This is potentially serious as aquaculture grows rapidly especially for prawn, a high value seafood whose consumer demands far exceeds the supply [2], [3].

Understanding heavy metals accumulation is crucial because of its potential to cause toxic effects in all living things. There are numerous studies shown that aquatic invertebrates tend to accumulate higher level of heavy metals and most of them can be bioindicator of heavy metal pollution. Prawn is considered by many as one of the good bioindicator in environmental monitoring studies [4]. Thus, the key research objective of this study is to identify and study selected heavy metals in Penaeus vannamei in the study area.

\section{MATERIALS AND METHOD}

The research area of this study is located in Kingfisher Inanam, Kota Kinabalu, the capital of Sabah (Fig. 1). Sabah is a part of Malaysia and it is located in the north of Borneo. The prawn samples were collected when it reached its maturity (5 months). After collection, the shrimps were kept in a cooler box $\left(4^{\circ} \mathrm{C}\right)$ and transported to the laboratory as soon as possible. Each shrimp was measured its physical parameters (weight and length), they were separated into head, shell and flesh. The samples were then rinsed with ultrapure water to remove foreign particles and patted dry with paper towels. Next, samples were dried under $60^{\circ} \mathrm{C}$ until samples reached constant weight. After that, the samples were frozen, freeze-dried, grounded into powder and homogenized.

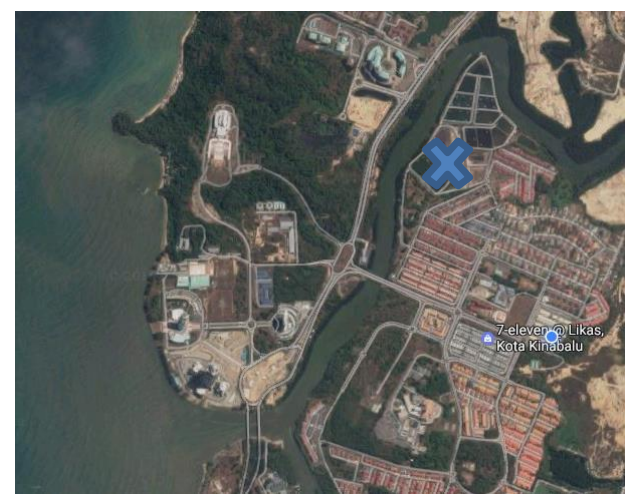

Fig. 1. Sampling location of this study (Marked "X").

The extraction of heavy metal of prawn was based on 
Standard Method 3030 G Nitric Acid - Sulphuric Acid Digestion Method [5]. A $5 \mathrm{ml}$ of conc. $\mathrm{H}_{2} \mathrm{SO}_{4}$ was added in a crucible with $2 \mathrm{ml}$ of sample. The sample underwent heating and $\mathrm{HNO}_{3}$ was added drop by drop. The sample was left to evaporate on a hot plate until dense white fumes of $\mathrm{SO}_{3}$ were released. Next, the solution was added with drop by drop of $\mathrm{HNO}_{3}$ and repeat evaporation until it obtained clear solution. All $\mathrm{HNO}_{3}$ was removed when the solution is clear and no brownish fumes are evident. The sample was left to cool and later it was diluted with $30 \mathrm{ml}$ of ultrapure water. Samples blank of each type of sampling and subject were prepared using the same method as mentioned. Ultrapure water is used for sample blank. All samples including blank were filter using syringe filter of $0.45 \mu \mathrm{m}$ prior of ICP - OES analysis. All samples were analysed three times to obtain mean concentration of heavy metals in prawn. The standard deviation was determined.

\section{RESULtS}

Results showed that $\mathrm{Fe}, \mathrm{Cu}$ and $\mathrm{Zn}$ are the most abundant elements in different parts of prawns whereas $\mathrm{Cd}$ and $\mathrm{Pb}$ are the least abundant elements detected. Based on Fig. 2, Fig. 3, Fig.4 and Fig. 5, the rank profile of average heavy metals levels in the analysed parts resulted as head $>$ shell $>$ flesh for $\mathrm{Mn}, \mathrm{Ni}, \mathrm{Pb}$ and $\mathrm{Cu}$ while head $>$ flesh $>$ shell for As and $\mathrm{Zn}$ whereas shell $>$ flesh $>$ head for $\mathrm{Cr}$ and $\mathrm{Fe}$. The $\mathrm{Cd}$ concentration was only found in the head of prawn.

The ranking profile of head for heavy metals concentration is $\mathrm{Fe}>\mathrm{Cu}>\mathrm{Zn}>\mathrm{Cr}>\mathrm{Mn}>\mathrm{As}>\mathrm{Ni}>\mathrm{Pb}>\mathrm{Cd}$ with respective mean concentration $(\mathrm{mg} / \mathrm{L})$ of $37.336 \pm 0.222,28.884 \pm 0.106$, $14.874 \pm 0.225, \quad 2.873 \pm 0.019, \quad 2.814 \pm 0.016, \quad 1.928 \pm 0.094$, $1.639 \pm 0.004,0.077 \pm 0.057$ and $0.020 \pm 0.005$. The highest mean concentration is Fe whereas the lowest concentration is Cd for the head of prawn.

The ranking profile of heavy metals concentration in flesh is $\mathrm{Fe}>\mathrm{Zn}>\mathrm{Cu}>\mathrm{Cr}>\mathrm{As}>\mathrm{Ni}>\mathrm{Mn}>\mathrm{Pb}$ with respective mean concentration $(\mathrm{mg} / \mathrm{L})$ of $9.200 \pm 0.118,2.381 \pm 0.021$, $1.087 \pm 0.023, \quad 0.924 \pm 0.010, \quad 0.549 \pm 0.018, \quad 0.446 \pm 0.003$, $0.239 \pm 0.004$ and $0.010 \pm 0.003$. The highest mean concentration is $\mathrm{Fe}$ while the least is $\mathrm{Pb}$.

The ranking profile of heavy metals concentration in shell is $\mathrm{Fe}>\mathrm{Cu}>\mathrm{Zn}>\mathrm{Cr}>\mathrm{Mn}>\mathrm{As}>\mathrm{Ni}>\mathrm{Pb}$ with respective mean concentration $(\mathrm{mg} / \mathrm{L})$ of $11.550 \pm 0.045,5.849 \pm 0.041$, $2.165 \pm 0.003, \quad 0.999 \pm 0.004, \quad 0.832 \pm 0.004, \quad 0.458 \pm 0.011$, $0.449 \pm 0.002$ and $0.023 \pm 0.008$. The highest mean concentration is $\mathrm{Fe}$ while the least is $\mathrm{Pb}$.

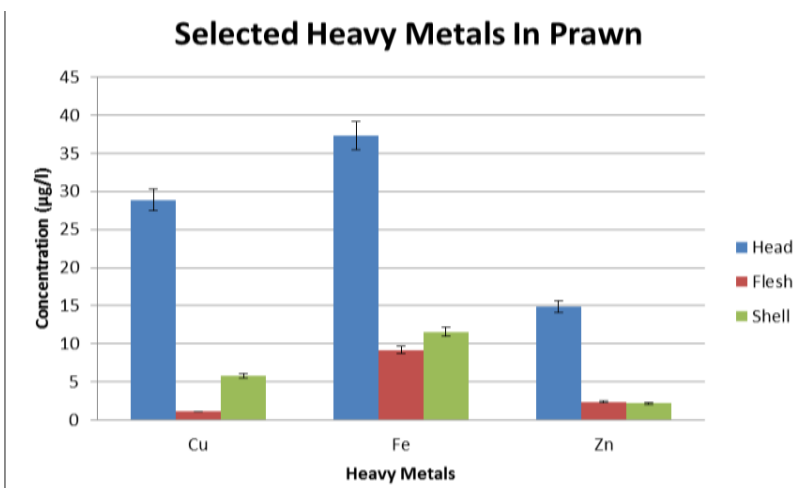

Fig. 2. Heavy metals concentration in prawn for $\mathrm{Cu}, \mathrm{Fe}$ and $\mathrm{Zn}$.

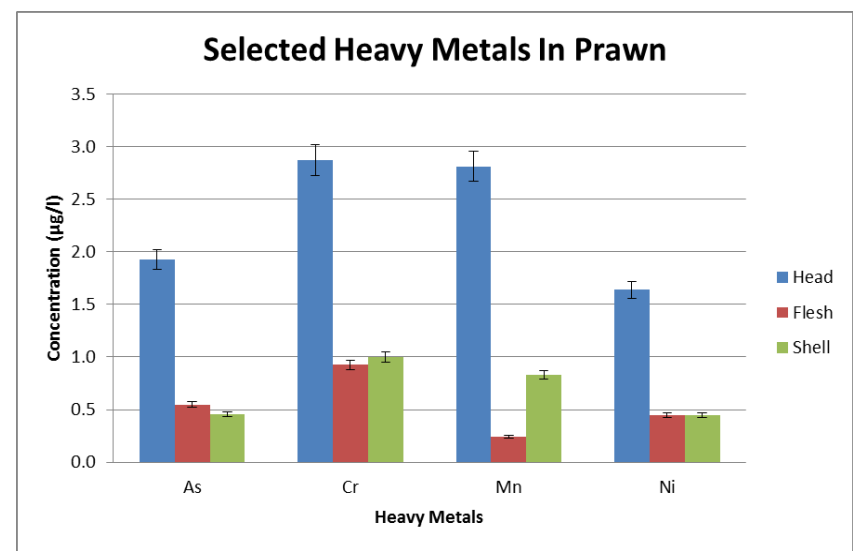

Fig. 3. Heavy metals concentration in prawn for $\mathrm{As}, \mathrm{Cr}, \mathrm{Mn}$ and $\mathrm{Ni}$

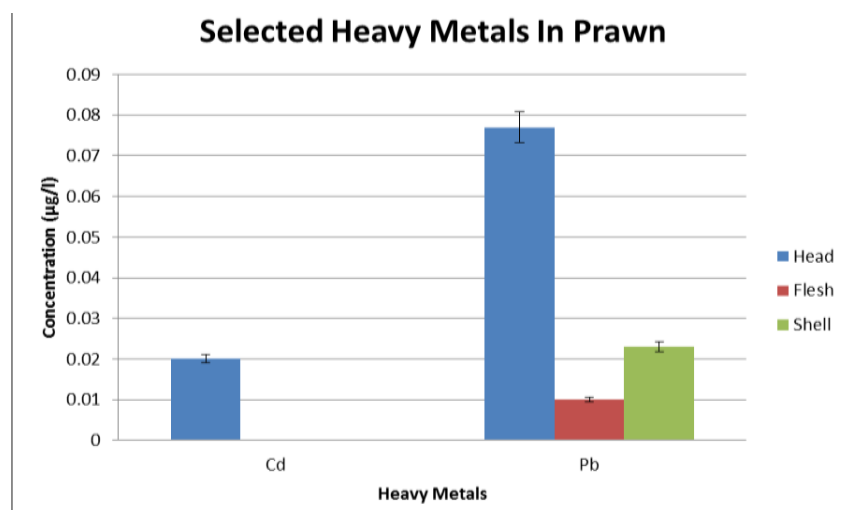

Fig. 4. Heavy metals concentration in Prawn for $\mathrm{Cd}$ and $\mathrm{Pb}$.

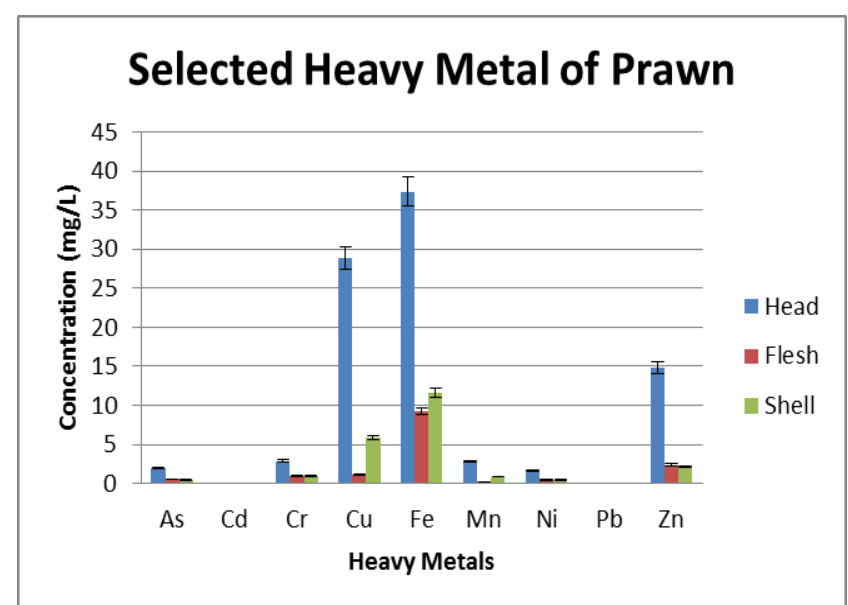

Fig. 5. Overall ranking profile of selected heavy metals according to its parts of prawn.

\section{DISCUSSION}

The water of the prawn pond which is originated from estuaries possibly contained a high load of heavy metals. This kind of situation has been seen in Sabah's coastal areas, where interaction between inshore water and land-based activities is intense [6]. Aquatic organisms are sensitive to metals when the concentration of these substances reaches a certain level in the water. This is especially in the case of prawn as invertebrates tend to accumulate more metal than fish [7]. Besides that, other factors such as condition of water quality in the pond, pond preparation, the seedlings, sediment quality and others can be contributing factors for bioaccumulation in prawn.

There are numerous abiotic factors affecting heavy metals level in prawns such as parts of prawn, seasonal variation and 
sexes. In this research, we focused on parts of prawn. Prawn heads contained the highest levels of heavy metals is not surprising, as the head contains the hepatopancreas or digestive gland. Hepatopancreas is an organ which is an essential metal storage site in decapod crustaceans [8]. Thus, the head of prawn is a good indicator tissue for metal monitoring compared to other parts of prawn. From the results of this study, the prawn head is not safe to consume. According to previous studies, accumulated cadmium is primarily concentrated in the hepatopancreas [9]. Hence, in others parts of prawn, it is not detectable.

The highest concentrations in all parts are Ferum, Fe with the ranking profile of head> shell> flesh. The function of hepatopancreas in prawn head is to regulate the transfer of dietary iron into the circulatory system. Environmentally availability and general cellular demands are influencing the iron uptake and utilization in species that have copper-based hemocyanin. According to [10], the concentration of iron in hepatopancreas increased linearly with dietary supplementation. This shows the hepatopancreas is serving as an excretory or storage organ. Thus, the presence of highest concentration of $\mathrm{Fe}$ in prawn head due to its function as storage organ of metals.

Concentration of $\mathrm{Zinc}, \mathrm{Zn}$ is the second highest in ranking profile of flesh while third in head and shell. The presence of zinc in viscera of prawn of natural water is much higher due to increase bioavailability of zinc in the aquatic environment and enzymatic role as regulator of several enzymes of hepatopancreas and glands in prawn's head [11]. The enzymatic activity regulated the metabolism of nucleic acid, carbohydrates and protein in the prawn. Hence, its concentration is higher in all parts of prawn compared to other trace element except $\mathrm{Fe}$ and $\mathrm{Cu}$. The ranking profile of $\mathrm{Zn}$ is head> flesh> shell due to the high affinity for metallothionein as zinc has low excretion rate and tends to accumulate inside the cell [12].

The concentration of Copper, $\mathrm{Cu}$ is second highest in ranking profile of head and shell of prawn. $\mathrm{Cu}$ plays an important role in oxygen-carrying pigment hemocyanin same as haemoglobin in the blood of vertebrates. However, it may become toxic when it exceeds a specific threshold. The input of copper into marine environment most probably are from municipal waste waters, manure, fertilizers, antifouling measures (paint and wood preservatives) and manufacturing industries wastes. In other hand, $\mathrm{Cu}$ is the cheapest and most commonly used pesticide in aquaculture industry and other aquatic systems [13]. Most of the antifoulants use copper as their active ingredient which can contribute to presence of copper in the aquatic environment which contaminate seafloor sediments around farm [14]. In this study, the concentration of $\mathrm{Cu}$ in prawn head, flesh and shell are 28.884 $\mathrm{mg} / \mathrm{L}, 1.087 \mathrm{mg} / \mathrm{L}$ and $5.849 \mathrm{mg} / \mathrm{L}$ respectively are found below the permissible limit as prescribed by WHO (30 ppm). The concentration of copper in prawn head is above permissible level of $10 \mathrm{ppm}$ for FAO maximum limits for prawn.

In marine environment, arsenic, As is often found in high concentration of organic form and it can go up to $50 \mathrm{mg} / \mathrm{kg}$ of arsenic on a wet weight basis in some seafood including seaweed, fish, shell fish, and crustaceans whereas it is normally found much lower (typically $0-20 \mu \mathrm{g} / \mathrm{kg}$ ) in livestock in fresh water and in the terrestrial environment. The amounts of arsenic found in this study are in the range of $0.458 \mathrm{mg} / \mathrm{L}$ to $1.928 \mathrm{mg} / \mathrm{L}$. Previous study showed that majority of As in prawn and crab appears to be in the form of less toxic organic form such an arsenobetaine. According to [8], the $8.28 \mathrm{mg} / \mathrm{L}$ in a sample is not sufficient to assess the risk from eating seafood and speciation analysis is necessary. In this study, the concentration level of arsenic is lower than $8.28 \mathrm{mg} / \mathrm{L}$, thus, it is not sufficient to assess the risk.

Chromium, Cr plays a role in glucose and lipid metabolism as an essential nutrient [4]. Hence, presence of small amount of $\mathrm{Cr}$ is essential for the growth of prawn. This study found that the concentration of Chromium $(2.87 \mathrm{mg} / \mathrm{L})$ in prawn head exceeded the maximum limits for prawn of FAO (1 ppm) [15] whereas prawn flesh and shell are $0.924 \mathrm{mg} / \mathrm{L}$ and 0.999 $\mathrm{mg} / \mathrm{L}$ are below the limits. Hence, the prawn head is not suitable for human consumption. The concentration of $\mathrm{Fe}$ and $\mathrm{Zn}$ in prawn head, flesh and shell are below the specific Maximum acceptable concentration WHO (1992) limits which is $100 \mathrm{ppm}(\mathrm{Fe})$ and $1000 \mathrm{ppm}(\mathrm{Zn})$ respectively [15].

Nickel, $\mathrm{Ni}$ is naturally occurring in soil and surface water with concentration lower than 100 and $0.005 \mathrm{ppm}$ respectively [16]. However, anthropogenic activities such as smelting, metal mining, vehicle emission, fossil fuel burning, disposal of household, municipal and industrial wastes, application of fertilizer and organic manures also contributing $\mathrm{Ni}$ in aquatic environment. In this study, the concentration of $\mathrm{Ni}$ found in head, flesh and shell are 1.639 $\mathrm{mg} / \mathrm{L}, 0.446 \mathrm{mg} / \mathrm{L}$ and $0.449 \mathrm{mg} / \mathrm{L}$ respectively are below the permissible level of WHO (0.5 ppm to $1.0 \mathrm{ppm})$ except prawn head.

Lead, $\mathrm{Pb}$ is a cumulative poison and potent enzyme inhibitor as it incorporates into enzymes structure [17]. It inhibit the synthesis of heam in organisms where it interferes the effective utilization of iron and blood circulation. The main sources of lead pollution in aquatic environment including effluents and emissions from industries, emission from vehicles running on leaded petrol, the smoke and dust emissions of coal and gas-fired power stations. In this study, we found that $\mathrm{Pb}$ concentration are $0.077 \mathrm{mg} / \mathrm{L}, 0.010 \mathrm{mg} / \mathrm{L}$ and $0.023 \mathrm{mg} / \mathrm{L}$ for prawn head, flesh and shell which are blow permissible level prescribed by WHO (0.5 ppm).

Manganese, $\mathrm{Mn}$ is essential biological function where it present in enzymes like oxidoreductases, transferases, hydrolases, lyases and isomerases. High consumption of manganese food can cause dermatitis, glucose metabolism issue, bad formation of bones and etc. Excess amount of manganese is toxicant and the nervous system is the most vulnerable to it. In this study, the concentration of manganese in prawn head, flesh and shell are $2.814 \mathrm{mg} / \mathrm{L}, 0.239 \mathrm{mg} / \mathrm{L}$ and $0.832 \mathrm{mg} / \mathrm{L}$ respectively are below the permissible level permitted by WHO (1 ppm) except prawn head.

Cadmium, $\mathrm{Cd}$ is a highly toxic metal which may enter into the aquatic bodies through run off from agricultural lands (rock phosphate fertilisers) and sewage sludge. Besides, paper, electroplating, mining, PVC plastic, pigments and ceramic industries, batteries and fossil fuel combustion may contribute to the presence of $\mathrm{Cd}$ in aquatic environment. Aquatic invertebrates take up cadmium and other trace 
elements from solution in their aquatic medium and diets which varies according to its bioavailability of the metals in water and food [18]. Most of the crustaceans do not regulate the uptake and excretion of cadmium with newly acquired concentrations being added to total body stores, mostly bound to metallothionein. Penaied prawns can effectively assimilate cadmium from dietary sources, and may be able to slowly excrete it via cadmium-rich granules from the hepatopancreas [19]. In this studies, Cd only found in the head of prawn $(0.020 \mathrm{mg} / \mathrm{L})$ which is above the permissible level of WHO (0.005 ppm).

\section{CONCLUSION}

The knowledge of heavy metal concentration in prawn is very important with respect to environmental management, human consumption of prawn and to determine the most useful bioindicator species and polluted area. Excessive amount of heavy metals in prawn is unsafe for human consumption due to its bioaccumulation abilities. Distribution pattern of toxic heavy metals is very important in tracking the accumulation of such pollutants in organism and the final transfer to human through seafood. In this study, the concentration of $\mathrm{As}, \mathrm{Fe}, \mathrm{Mn}, \mathrm{Ni}, \mathrm{Pb}$ and $\mathrm{Zn}$ are below the permitted level of FAO except $\mathrm{Cd}, \mathrm{Cu}$ and $\mathrm{Cr}$. The present study shows the ranking profile of heavy metals concentration is $\mathrm{Fe}>\mathrm{Cu}>\mathrm{Zn}>\mathrm{Cr}>\mathrm{Mn}>\mathrm{As}>\mathrm{Ni}>\mathrm{Pb}>\mathrm{Cd}$. Most of the heavy metals are accumulated in the head of the prawn.

\section{ACKNOWLEDGEMENT}

Authors are thankful to the aquaculture company for providing research area and prawn samples for analysis. This research is funded by project grant of NRGS0005 under Ministry of Higher Education, Malaysia.

\section{REFERENCES}

[1] A. Wilfart, J. Prudhomme, J. P. Blancheton, and J. Aubin, "LCA and emergy accounting of aquaculture systems: Towards ecological intensification," Journal of Environmental Management, vol. 121, pp. 96-109, Jan 2013.

[2] S. C. Caeiro, M. H. Costa, T. B. Ramos, F. Fernandes, N. Silveira, A. Coimbra, G. Medeiros, and M. Painho, "Assessing heavy metal contamination in Sado Estuary sediment: An index analysis approach," Ecological Indicators, vol. 5, pp. 151-169, 2005

[3] R. Sharif, A. R. Ghazali, N. F. Rajab, H. Haron, and F. Osman, "Toxicological evaluation of some Malaysia locally processed raw food products," Food and Chemical Toxicology, vol. 46, pp. 368-374. Jan 2008.

[4] G. V. Zodape, "Evaluation of metals in commercially important prawns and shrimps species collected from Virar market of extended Mumbai suburb of (west coast) India," Indian Journal of Applied Research, vol. 4, pp. 598-602, Oct. 2014.

[5] APHA, Standard Methods for the Examination of Water and Waste Water, American Public Health Association, New York, USA, 1995.

[6] M. I. Hashmi, S. Mustafa, and S. A. Tariq, "Heavy metal concentrations in water and tiger prawn (penaeus monodon) from grow-out farms in Sabah, North Borneo," Food Chemistry, vol. 79, pp. 151-156, Nov. 2002

[7] D. J. H. Phillips and P. S. Rainbow, Biomonitoring of Trace Aquatic Contaminants, Elsevier Science, Barking, UK 1993.

[8] M. Heidarieh, M. G. Maragheh, M. A. Shamami, M. Behgar, F. Ziaei, and Z. Akbari, "Evaluate of heavy metal concentration in shrimp (penaeus semisulcatus) and crab (portunus pelagicus) with INAA method," Springer Plus, vol. 2, pp. 72, Feb. 2013.

[9] A. Alliot and M. Frenet-Piron, "Relationship between metals in sea-water \& metal accumulation in shrimps," Marine Pollution Bulletin, vol. 21, no. 1, pp. 30-33, Jan. 1990

[10] G. W. Bryan, "Concentration of zinc and copper in tile tissues of decapod crustaceans," Journal Marine Biological Association of the United Kingdom, vol. 48, pp. 303-32 I. 1968.

[11] D. A. Davis, A. L. Lawrence, and D. M. Gatlin III, "Evaluation of the Dietary Iron Requirement of Penaeus vannamei," Journal of The World Aquaculture Society, 1st ed, vol 23, pp. 15-22, March 1992

[12] G. W. Bryan and W. I. Langston, "Bioavailability, accumulation and effects of heavy metals in sediments with special reference to United Kingdom estuaries: A review," Environmental Pollution, vol. 76, no. 2, pp. 89-131. 1992

[13] W. Y. Chen, Y. R. Ju, C. J. Lin, J. W. Tsai, S. C. Chen, and C. M. Liao, "Environmental Stochasticity promotes copper bioaccumulation and bioenergetics response in Tilapia," Stochastic Environmental Research Risk Assessment, vol. 29, no. 6, pp. 1545-1555, 2014.

[14] Science for Environment Policy, Sustainable Aquaculture Future Brief 11, UWE, Bristol, 2015.

[15] FAO/WHO, Codex Alimentarius Commission, Standard Program Codex Committee on Food Additives and Contaminants, 24th Session, Hague, 23-28, March, 1992.

[16] G. Rathor, N. Chopra, and T. Adhikari, "Nickel as a pollutant and its management," International Research Journal of Environment Sciences, vol. 3, no. 10, pp. 94-98, 2014.

[17] C. I. Nsofor, I. O. Igwilo, O. O. Ikpeze, C. F. Ikeogu, F. O. Umeoguagu, and C. J. Okonkwo, "Bioaccumulation of heavy metals in Shellfish Macrobrachium rosenbergi in Niger River at Onitsha, Anambra State, Nigeria," International Journal of Agriculture and Biosciences, vol. 3 , no. 1, pp. 38-40, 2014.

[18] M. C. R. Amaral, A. M. F. Rebelo, J. P. M. Torres, and W. C. Pfeiffer, "Bioaccumulation and depuration of $\mathrm{Zn}$ and $\mathrm{Cd}$ in mangrove oysters Crassostrea rhizophorae, Guilding. (1828) transplanted to and from a contaminated tropical coastal lagoon," Marine Environmental Research, vol. 59, no. 4, pp. 277-285, May 2005.

[19] I. Stewart, J. Tan, R. Kenyon, A. Kiermeier, N. Malhi, A. Sehmbi, and C. McLeod, 2014, 2012-13 Survey of Australian Wild-Caught Prawns for Analysis of Cadmium and Selenium, Project No. 2009/787, SARDI Food Safety and Innovation.

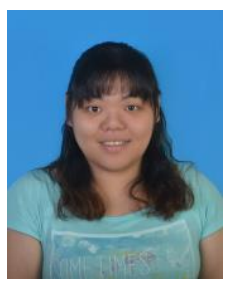

Lee Wei Peng is a MSc candidate in environmental SCIENCE at the Faculty of Science and Natural Resources of Universiti Malaysia Sabah, Malaysia. Her current research focus is into environmental pollutants in aquaculture ponds.

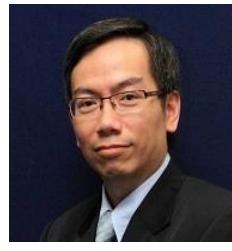

Vun Leong Wan received his $\mathrm{PhD}$ degree from Universiti Kebangsaan Malaysia. He is currently a senior lecturer at the Faculty of Science and Natural Resources in Universiti Malaysia Sabah, Malaysia. He specializes in environmental management.

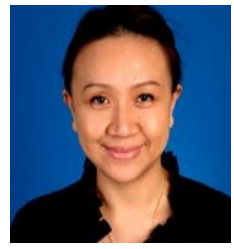

Carolyn Melissa Payus received her $\mathrm{PhD}$ degree from Universiti Kebangsaan Malaysia. She is currently the Head of Environmental Science Programme. She specializes in drinking water quality standards, environmental risk assessment and bionomics, air pollution and atmospheric chemistry.

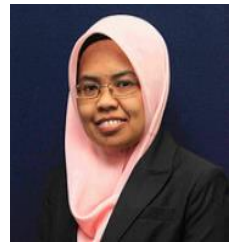

Siti Aishah Mohd Ali received her MSc degree in Universiti Malaysia Sabah. She is currently a lecturer in Universiti Malaysia Sabah. She specializes in environmental chemistry. 